\title{
片持ばりの Negative Shear Lag の解析とその応用* RESEARCHES ON NEGATIVE SHEAR LAG OF CANTILEVER BEAMS AND APPLICATION TO BRIGDE DESIGN
}

\author{
中 井博** ・ 村 山 泰 男*** \\ By Hiroshi NAKAI and Yasuo MURAYAMA
}

\section{1. まえがき}

周知のように, 幅の広いフランジ・プレートを持つ単 純ばりでは，どの断面においてもフランジ・プレート内 の垂直応力がウェブとの接合点において最大となり，フ ランジ・プレートの中央に進むにしたがって応力が漸減 するといらいわゆる Shear lag 現象を伴うことが古くか ら知られていた ${ }^{12,2)}$. 片持ばりの固定端においてもこの 現象が発生するが3)，固定端より若干離れた断面におい ては端部の大きな拘束による反転現象がおこり，フラン ジ中央部の垂直态力のほうがウェブ結合点の值よりも大 きくなることが明らかにされている.

$\mathrm{Kuhn}^{4)}$ は航空機の翼を対象にした解析を行い，この種 の現象を Negative shear lag と名付けている.わが国 でも林ら 断遅れが反対になることから，せん断進み(Shear lead) という用語を用いている．いずれにしても，片持ばりの shear lag 現象が逆転することを意味するものであるか ら，本文ではこの現象を Kuhn にしたがい Negative shear lag とよぶことにする.

ところで, 土木構造物でも最近は単純ばりと異なった 境界条件を持つものが建設される機会が多く，たとえば 連続桁橋を片持式架設工法で建設する際には，その基本 構造形式は片持ばりであるから，上述の Negative shear lag が起こることになる．また，連続桁橋で中間支点の 間隔が狭い場合，その支間は負の曲げモーメントが卓越 し, Negative shear lag を呈することが小松(6)によって 明らかにされている．さらに，著者らによると斜張橋の ケーブル取付点においても同様な現象が起こることが示 されている7 .したがって，その基本となる片持ばりの

* 第 30 回土木学会年次学術講演会において発表, I-104, (昭. 50.10)

** 正会員 工博 大阪市立大学教授 工学部土木工学科

*** 学生会員 大阪市立大学大学院工学研究科修士課程在学中
Shear lag 現象を解析し, Negative shear lag に関す る特性を明確にしておくことは重要であると考える。

そこで, 本文は近藤・小松・中井 ${ }^{8)}$ によって導びかれ た鋼床版桁橋の Shear lag に関する基礎式を用い，片持 ばりに対する解を求めたものである. そして，片持ばり の Negative shear lag が起こる (1) 範囲, (2) 最大位置 を求め, (3) それらが各種のパラメーターによってどの ように変動するかを明らかにしようとしたものである。

これまで Shear lag 現象を考慮し，しかも初等ばり 理論による簡便な設計計算を行うために有効幅8)を考え てきたが， Negative shear lag が生ずる場合に対して も，別途有効幅を求めることができる．しかし，繁雑に なる点も多々あるので本文では実用的見地より初等ばり 理論によって得られた垂直応力を修正し, Negative shear lag による垂直応力が容易に算定できる実用公式を 提案する. 一方, 理論解析結果の妥当性を検討するため に，軽量型鋼を若干加工した $I I$ 形断面の片持ばり模型 を製作して実験を行ったそとて，各種の載荷状態のも とにおける $I$ 型断面内の垂直応力分布やたわみの実測 值と計算值とを比較し，本文の理論解析方法の妥当性に ついて種々考察するものである。

最後に，本文で求めた片持ばりに関する基本解を用い て，種々な形式の鋼床版桁橋に応用する方法を述べる. すなわち，(1) 架設途上の連続桁橋，(2) 不等スパン連続 桁橋, (3) 斜張橋などを片持ばりに置換して Negative shear lag を解析するための等価スパンの取り方，提案 公式の使い方，および Negative shear lag による垂直 応力の算定方法を数值計算例によって示すものである.

\section{2. 基本式と片持ばりに対する解}

\section{（1）記号の定義}

図一1 は本文で解析の対象とする $\Pi$ 形断面を有する 鋼床版析橋を示すが, 箱形断面などの換算方法は文献 8) 


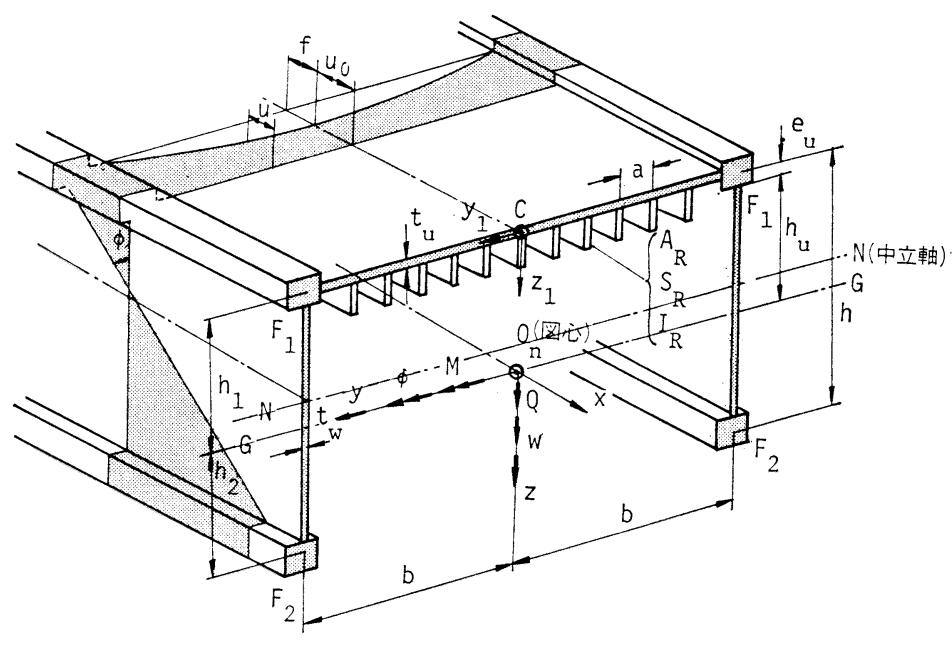

図一1 II 形断面を有する鋼床版桁橋

表一1 基本諸量

\begin{tabular}{|c|c|c|}
\hline 部 材 & 記 号 & 定 \\
\hline 鋼 & $t_{u}$ & デッキプレートの板厚 \\
\hline 床 & $\begin{array}{c}a \\
A_{R}\end{array}$ & 綪リフ11個の断面皘 \\
\hline 版 & $S_{R}$ & 縦リブ1個のデッキプレート中央面に関する断面 1 \\
\hline 部 & $I_{R}$ & 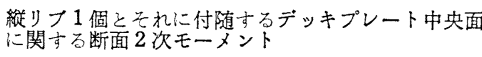 \\
\hline \multirow{3}{*}{ 主 } & $h$ & 桁高 \\
\hline & $t_{w}$ & 腹板の厚さ \\
\hline & $b$ & 腹板間隔の半分 \\
\hline \multirow{2}{*}{ 柠 } & $F_{1}$ & フラケットの断面積 \\
\hline & $F_{2}$ & 下フランジの断面積 \\
\hline
\end{tabular}

\section{表一2 断面諸}

\begin{tabular}{|c|c|c|c|c|}
\hline 部材 & 記号 & 定 & 算定公式 & 式番号 \\
\hline \multirow{2}{*}{ 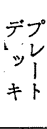 } & $\overline{\boldsymbol{t}}_{u}$ & デッキプレートの換算厚さ & $\bar{t}_{u}=\frac{t_{u}}{1-\nu^{2}}+\frac{A_{R}}{a}$ & (1) \\
\hline & $e_{u}$ & 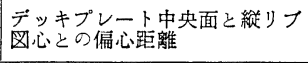 & $e_{u}=\frac{S_{R}}{a \bar{t}_{u}}$ & (2) \\
\hline \multirow{4}{*}{ 主 } & $F_{u}$ & 片側デッキプレートの断面積 & $F_{u}=b \bar{t}_{u}$ & (3) \\
\hline & $F_{w}$ & 片側腹板の断面積 & $F_{w}=\frac{t_{w} h}{1-\nu^{2}}$ & (4) \\
\hline & $F$ & 桁の総断面積の半分 & $\begin{aligned} & F=F_{u}+F_{w} \\
&+F_{1}+F_{2} \\
&\end{aligned}$ & (5) \\
\hline & $h_{1}$ & $\begin{array}{l}\text { 因心 } O_{n} \text { かデッキプレート中 } \\
\text { 央面までの鉛直距離 }\end{array}$ & $\begin{array}{l}h_{1}=\frac{1}{2 F}\left\{\left(2 F_{2}\right.\right. \\
\left.\left.+F_{w}\right) h+\frac{2 b}{a} S_{R}\right\}\end{array} \mid$ & (6) \\
\hline & $h_{2}$ & $\begin{array}{l}\text { 凷 } O_{n} \text { から下フランジ中央面 } \\
\text { までの鉛直距離 }\end{array}$ & $h_{2}=h-h_{1}$ & (7) \\
\hline \multirow{3}{*}{ 枌 } & $h_{u}$ & $\begin{array}{l}\text { 四心 } O_{n} \text { からデッキプレート中 } \\
\text { 立軸をでの鉛直距離 }\end{array}$ & $h_{u}=h_{1}-e_{u}$ & (8) \\
\hline & $I$ & 椌の断面 2 次モーメント & $\begin{aligned} I= & 2\left\{F_{u} h_{u}{ }^{2}+\left(h^{2} / 3\right.\right. \\
& \left.\left.-h_{1} h_{2}\right) F_{w}\right\} \\
& +\frac{b}{a} I R+F_{1} h_{1}{ }^{2} \\
& +F_{2} h_{2}{ }^{2}\end{aligned}$ & (9) \\
\hline & $W_{u}$ & デッキプレート中立面における & $W_{\boldsymbol{u}}=\frac{\left(1-\nu^{2}\right) I}{h_{\boldsymbol{u}}}$ & (10) \\
\hline
\end{tabular}

にゆずることにする.

まず，断面諸量の基本的なものを表 -1 に示す.

またこれらの記号を用いて計算さ れる断面諸量を表一2 に示す.

次に, 断面力・変位は表一3に示文 ように定義する.

\section{（2）基 本 式}

a) 断面力のつり合い

等分布荷重 $q$ が満載する場合, あ るいは集中荷重 $P$ が $x=c$ 点に載荷 する場合, 曲げモーメント $M$ に関す る基礎式は

$$
\frac{d^{2} M}{d x^{2}}=-\left\{\begin{array}{ll}
q & : \text { 等分布荷重 } \\
P \cdot \delta(x-c) & : \text { 集中荷重 }
\end{array}\right\}
$$

で与えられる。

ここで, $\delta$ はirac の delta function であり次式の ように定義されるものである.

$$
\left.\begin{array}{rl}
\delta(x-c) & =1: x=c \\
& =0: x \neq c
\end{array}\right\}
$$

b）断面力と変形量との関係式

図一1に示したように, shear lag 現象によって生ず

\begin{tabular}{|c|c|c|c|}
\hline 記号 & 定 & 算定公式 & 式番号 \\
\hline$u_{0}$ & 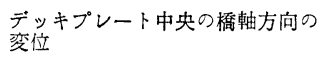 & $u_{0}=h_{1} \varphi-\frac{2}{3} \frac{F_{u}}{F} f$ & (11) \\
\hline$f$ & $\begin{array}{l}\text { Shear lag:よるデッキプレート } \\
\text { 中央の橋軸方向の变位 }\end{array}$ & \multicolumn{2}{|c|}{ (後述する) } \\
\hline 0 & 水平軸 $(y)$ まわりのたわみ角 & $\varphi=-\frac{d w}{d x}$ & (12) \\
\hline$w$ & 鉛直軸 $(z)$ 方向のたわみ & \multicolumn{2}{|c|}{ (後 述する) } \\
\hline$M$ & 曲げモーメント & \multicolumn{2}{|c|}{ (後述 する) } \\
\hline$m$ & Shear lagによる付加モーメント & \multicolumn{2}{|c|}{ (後 述 する) } \\
\hline$Q$ & 亡ん断力 & $Q=\frac{d M}{d x}$ & (13) \\
\hline
\end{tabular}

表一3 断面力・変位

\begin{tabular}{|c|c|c|c|}
\hline $\begin{array}{l}\text { パラメ } \\
\text {-ター }\end{array}$ & 定 & 算定 公 式 & 式番号 \\
\hline$\alpha$ & $\begin{array}{l}\text { 断面特性を表わすパラメー } \\
\text { 多かの }\end{array}$ & $\alpha=\frac{1}{b} \sqrt{\frac{1.5}{\omega(1.2-\pi)}}$ & (17) \\
\hline$\beta$ & 無次元パラメーター & $\beta=\frac{1.5}{1.2-\kappa}$ & (18) \\
\hline$r$ & 剛比を表わすパラメーター & $r=\frac{4}{3} \cdot \frac{F_{u} h_{u}{ }^{2}}{I}$ & (19) \\
\hline$\omega$ & $\begin{array}{l}\text { デッキプレートの材料・寸 } \\
\text { 法の特性を表わすハハラメー } \\
\text { ター }\end{array}$ & $\omega=\frac{1}{1-\nu}+\frac{A_{R}}{a t_{u}}(1+\nu)$ & (20) \\
\hline$\kappa$ & $\begin{array}{l}\text { 桁の断面形状を表わすパラ } \\
\text { メーター }\end{array}$ & $x=\frac{F_{u}}{F}+2 \frac{F_{u} h_{u}{ }^{2}}{I}$ & (21) \\
\hline
\end{tabular}

表-4 各種パラメーター 
表一5 各種荷重状態に対する断面力の解

\begin{tabular}{|c|c|c|c|}
\hline 載荷状態 & 曲 ナ゙ モ メ ント $M(x)$ & 断 力 & 式番号 \\
\hline 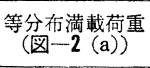 & $-\frac{q l^{2}}{2}\left(1-\frac{x}{l}\right)^{2}$ & $q l\left(1-\frac{x}{l}\right)$ & $(32.1)$ \\
\hline 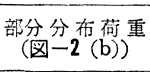 & $q c^{2}\left\{-2 \frac{a}{c}+2 \frac{a x}{c^{2}}-\frac{\left(x-c_{1}\right)^{2}}{2 c^{2}} U\left(x-c_{1}\right)+\frac{\left(x-c_{2}\right)^{2}}{2 c^{2}} U\left(x-c_{2}\right)\right\}$ & $q c\left\{2 \frac{a}{c}-\frac{x-c_{1}}{c} U\left(x-c_{1}\right)+\frac{x-c_{2}}{c} U\left(x-c_{2}\right)\right\}$ & $(32.2)$ \\
\hline 集中 (荷 $(\mathrm{c}))^{\text {重 }}$ & $P C\left(\frac{x}{c}-1\right)\{1-U(x-c)\}$ & $P\{1-U(x-c)\}$ & $(32.3)$ \\
\hline
\end{tabular}

るデッキプレート内の橋軸方向変位 $f$ に関する基礎式 は，文献 8）より次式のように与えられる.

$$
\frac{d^{2} f}{d x^{2}}-\alpha^{2} f=\frac{\beta h_{u}}{E I} Q \text {. }
$$

ただし， $E$ は鋼材のヤング率であり，また，表一4に 示すパラメーターを導入するものとする.

すると，たわみwの基礎式は文献 8) より次のように 書くことができる.

$$
\frac{d^{2} w}{d x^{2}}=-\frac{M}{E I}-\frac{r}{h_{u}} \frac{d f}{d x}
$$

c）垂直応力の算定公式

図一1 に示したようにデッキプレート中央点 $C$ から 任意の点 $\left(y_{1}, z_{1}\right)$ における橋軸方向の変位 $u$ は, 文献 8）より次式のように与えられる.

$$
u=\left(h_{1}-z_{1}\right) \varphi+\left(1-\frac{y_{1}^{2}}{b^{2}}-\frac{2}{3} \cdot \frac{F_{u}}{F}\right) f
$$

そこで, Hooke の法則よりその点の 垂直応力を求める と, 式 (12)より

$$
\begin{aligned}
\sigma_{x}= & E \frac{d x}{d x} \\
= & E\left[\left(h_{1}-z_{1}\right) \frac{d \varphi}{d x}+\left(1-\frac{y_{1}{ }^{2}}{b^{2}}-\frac{2}{3} \cdot \frac{F_{u}}{F}\right) \frac{d f}{d x}\right] \\
= & -\left[\frac{M}{I}\left(h_{1}-z_{1}\right)-E\left\{1-\frac{y_{1}{ }^{2}}{b^{2}}-\frac{2}{3} \cdot \frac{F_{u}}{F}\right.\right. \\
& \left.\left.-\left(h_{1}-z_{1}\right) \frac{\gamma}{h_{u}}\right\} \frac{d f}{d x}\right]
\end{aligned}
$$

が得られる。

ここで, shear lag による付加モーメント $m$ を次の ように定義する.

$$
m=\frac{E I}{h_{u}} \cdot \frac{d f}{d x}
$$

すると, デッキプレートにおける垂直応力分布は, 式 (10)の $W_{u}$ を用いて

$$
\begin{aligned}
\sigma_{x}= & -\frac{1}{W_{u}}\left[\frac{h_{1}-z_{1}}{h_{u}} M-\left\{1-\frac{y_{1}^{2}}{b^{2}}-\frac{2}{3} \cdot \frac{F_{u}}{F}\right.\right. \\
& \left.\left.-\left(h_{1}-z_{1}\right) \frac{r}{h_{u}}\right\} m\right] \ldots \ldots \ldots \ldots \ldots \cdots \cdots \cdots \cdots \cdots \cdots \cdots \cdots \cdots
\end{aligned}
$$

と表わされ，ウェブプレートにおいては

* 文献 7)によると，物理的に付加モーメントは

$$
m=\gamma \frac{E I}{h_{u}} \cdot \frac{d f}{d x}
$$

であるがここでは簡便のためにこのようにおくことにし た.

$$
\sigma_{x}=\frac{1}{W_{u}}\left[\frac{z}{h_{u}} M-\left(\frac{2}{3} \cdot \frac{F_{u}}{F}-z \frac{r}{h_{u}}\right) m\right] \cdots
$$

と書くことができる.

特に, デッキプレートの中立軸 $h_{u}$ における垂直応力 の公式は，以下のように簡素化することができる.

デッキプレート中央 :

$$
\sigma_{m}=-\frac{1}{W_{u}}\left[M-\left(1-\frac{2}{3} \kappa\right) m\right]
$$

ウェブとの接合点 :

$$
\sigma_{e}=-\frac{1}{W_{u}}\left[M+\frac{2}{3} \kappa m\right]
$$

また, 付加モーメント $m$ による垂直応力を $\sigma_{s}$ とすれば

$$
\sigma_{s}=\frac{m}{W_{u}}
$$

となり，デッキプレート中立軸内の任意点 $y_{1}$ における 垂直応力 $\sigma_{x}$ は, 次式で与えられる.

$$
\sigma_{x}=\sigma_{m}-\sigma_{s} \cdot\left(\frac{y_{1}}{b}\right)^{2}
$$

式（27）（29）の公式はデッキプレート中立軸に関す るものであるが, 縁応力を求めたいとき， $W_{u}$ の代わり に縁における断面係数を用いてもその誤差は僅少である と考えられる.

\section{（3）片持ばりに対する解}

以上に示した基礎式を片持ばりに対して解く. 荷重状 態としては図一2に示す 3 つの代表的なものを考えるこ とにする。

（a）等分布満載荷重

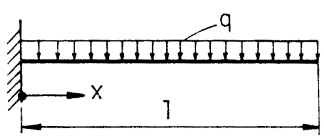

（b）部分分布荷重

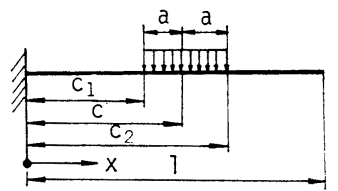

（c）集中荷重

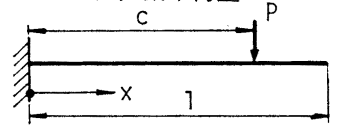

図一2 荷重状態 
表一6 Shaer lag による軸方向変位 $f(x)$ の解

\begin{tabular}{|c|c|c|}
\hline 載 荷 状 態 & $f(x)$ & 式番号 \\
\hline 等分布満載荷重 (図一2 (a)) & $\frac{q h_{u} \beta}{E I \alpha^{3}}\left[\frac{1}{\cosh \alpha l}\{\alpha l \cosh \alpha(l-x)-\sinh \alpha x\}-\alpha(l-x)\right]$ & $(34.1)$ \\
\hline 部分分布荷重 (図一2 (b)) & $\begin{aligned} \frac{q h_{u} \beta}{E I \alpha^{3}}[ & \frac{2}{\cosh \alpha l}\{\sinh \alpha(l-x) \cdot \sinh \alpha a-\alpha a \sinh \alpha l\} \sinh \alpha x+2 \alpha a(\cosh \alpha x-1) \\
& \left.-\left\{\sinh \alpha\left(x-c_{1}\right)-\alpha\left(x-c_{1}\right)\right\} U\left(x-c_{1}\right)+\left\{\sinh \alpha\left(x-c_{2}\right)-\alpha\left(x-c_{2}\right)\right\} U\left(x-c_{2}\right)\right]\end{aligned}$ & $(34.2)$ \\
\hline 集 中 荷 重 (図一2（c)) & $\frac{P h_{u} \beta}{E I \alpha^{2}}\left[\frac{1}{\cosh \alpha l}\{\cosh \alpha(l-x)+\sinh \alpha x \cdot \sinh \alpha(l-c)\}-1-\{\cosh \alpha(x-c)-1\} U(x-c)\right]$ & $(34.3)$ \\
\hline
\end{tabular}

表一7 Shear lag による付加モーメント $\boldsymbol{m}(\boldsymbol{x})$ の解

\begin{tabular}{|c|c|c|}
\hline 載 荷 状 態 & $m(x)$ & 式番号 \\
\hline 等分布満載荷重（図一2（a)） & $q b^{2} \omega\left[\frac{-1}{\cosh \alpha l}\{\alpha l \sinh \alpha(l-x)+\cosh \alpha x\}+1\right]$ & $(35.1)$ \\
\hline 部分分布荷重 (図一2 (b)) & $\begin{aligned} q b^{2} \omega\left[\frac{2}{\cosh \alpha l}\{\right. & \sinh \alpha(l-c) \sinh \alpha a-\alpha a \sinh \alpha l\} \cosh \alpha x+2 \alpha a \sinh \alpha x \\
& \left.-\left\{\cosh \alpha\left(x-c_{1}\right)-1\right\} U\left(x-c_{1}\right)+\left\{\cosh \alpha\left(x-c_{2}\right)-1\right\} U\left(x-c_{2}\right)\right]\end{aligned}$ & $(35.2)$ \\
\hline 集 中 荷 重 (図一2(c)) & $P b \sqrt{\beta \omega}\left[\frac{-1}{\cosh \alpha l}\{\sinh \alpha(l-x)-\sinh \alpha(l-c) \cdot \cosh \alpha x\}-\sinh \alpha(x-c) U(x-c)\right]$ & $(35.3)$ \\
\hline
\end{tabular}

表一8 たわみ $\boldsymbol{w}(\boldsymbol{x})$ の解

\begin{tabular}{|c|c|c|}
\hline 載 荷 状 態 & $w(x)$ & 式番号 \\
\hline 等分布満載荷重（図一2（a)） & $\begin{aligned} \frac{q l^{4}}{E I}\left[\frac{1}{4}\left(\frac{x}{l}\right)^{2}\right. & \left.-\frac{1}{6}\left(\frac{x}{l}\right)^{3}+\frac{1}{24}\left(\frac{x}{l}\right)^{4}\right] \\
& +\frac{q r \beta}{E I \alpha^{4}}\left[\frac{-1}{\cosh \alpha l}\{\alpha l(\sinh \alpha l-\sinh \alpha x)-\cosh \alpha x+1\}-\alpha^{2} x\left(\frac{x}{2}-l\right)\right]\end{aligned}$ & (37.1) \\
\hline 部分分布荷重 (図一2 (b)) & $\begin{aligned} \frac{q l^{4}}{E I}\left[\frac{a c}{l^{2}}\left(\frac{x}{l}\right)^{2}\right. & \left.-\frac{1}{3} \frac{a}{l}\left(\frac{x}{l}\right)^{2}+\frac{1}{24}\left(\frac{x-c_{1}}{l}\right)^{4} U\left(x-c_{1}\right)-\frac{1}{24}\left(\frac{x-c_{2}}{l}\right)^{4} U\left(x-c_{2}\right)\right] \\
& +\frac{q r \beta}{E I \alpha^{4}}\left[\frac{2}{\cosh \alpha l}\{\sinh \alpha(l-c) \sinh \alpha a \cdot(1-\cosh \alpha x)+a \alpha(\sinh \alpha(l-x)\right. \\
& -\sinh \alpha l+\alpha x \cosh \alpha l)\}+\left\{\cosh \alpha\left(x-c_{1}\right)-\frac{\alpha^{2}\left(x-c_{1}\right)^{2}}{2}-1\right\} U\left(x-c_{1}\right) \\
& \left.-\left\{\cosh \alpha\left(x-c_{2}\right)-\frac{\alpha^{2}\left(x-c_{2}\right)^{2}}{2}-1\right\} U\left(x-c_{2}\right)\right]\end{aligned}$ & $(37.2)$ \\
\hline 集 中 荷 重 (図一2（c)) & $\begin{aligned} \frac{P c^{3}}{E I}\left[\frac{1}{2}\left(\frac{x}{c}\right)^{2}\right. & \left.-\frac{1}{6}\left(\frac{x}{c}\right)^{3}+\frac{1}{6}\left(\frac{x-c}{c}\right)^{3} U(x-c)\right] \\
& +\frac{P r \beta}{E I \alpha^{3}}\left[\frac{1}{\cosh a l}\{\sinh \alpha(l-x)-\sinh \alpha(l-c) \cosh \alpha x-\sinh \alpha l+\sinh \alpha(l-c)\}\right. \\
& +\alpha x+\{\sinh \alpha(x-c)-\alpha(x-c)\} U(x-c)]\end{aligned}$ & $(37.3)$ \\
\hline
\end{tabular}

\section{a) 断面力の解}

式（13）（14）を図一2に示す片持ばりの境界条件 $[M]_{x=l}=[Q]_{x=l}=0$.

のもとに解いた結果を表一 5 に示す.

この表で, $U$ は Unit step function を意味し，たと えば

$$
\left.\begin{array}{rl}
U(x-c) & =0 ; 0<x<c \\
& =1 ; c \leq x \leq l
\end{array}\right\}
$$

なることを表わすものこする。

\section{b) 変 位}

表一5 のせん断力 $Q$ を用いて，まず式 (16) より $f$ を求めるが, 境界条件は

$$
[f]_{x=0}=\left[\frac{d f}{d x}\right]_{x=l}=0
$$

である. 表一6には代表的な荷重状態に対する $f$ の解 を示す.
また, 表一7は, 上記の荷重状態に対する付加モーメ ント $m$ の解であり, 式 (24) より求められるものであ る.

最後に，たわみ $w$ は式 (22) を境界条件

$$
[w]_{x=0}=[\varphi]_{x=0}=0
$$

のもとに解くと, 表一8 の結果を得る.

\section{Negative shear lag の特性}

\section{（1）デッキプレートの垂直応力のスパン方向におけ る変化}

一般的な場合として $l / b=10$, パラメーター $\omega=2.0$, $\kappa=0.75$ として ${ }^{8)}$, (1) 等分布荷重が満載する場合, およ び (2) 集中荷重が $c=0.5 l$ 点に載荷する場合に対する デッキプレートの垂直応力の変化を 図一3〜 4 に示す. 


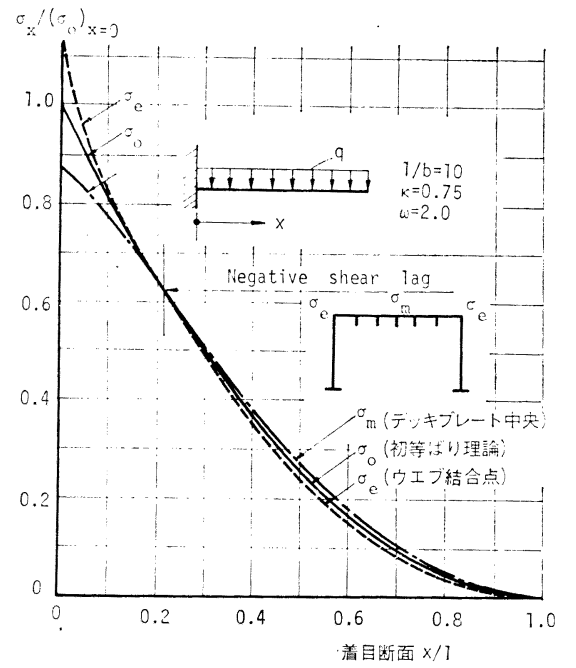

図一3 等分布荷重による垂直応カのスパン方向の変化

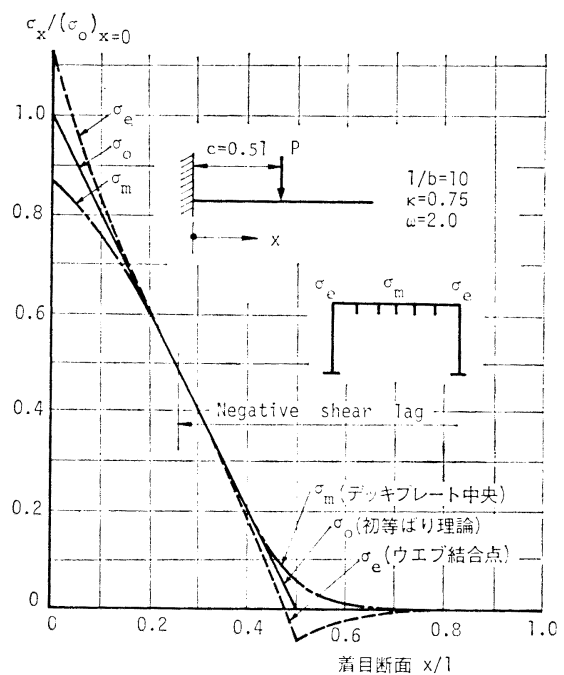

図-4 集中荷重による垂直応カのスパン方向の変化

ただしここでは (1) デッキプレート中央の值 $\sigma_{m}$, (2) ウェブとの接合点における值 $\sigma_{e}$ のほ か, 参考のために (3) 初等ばり理論による值 $\sigma_{0}$ も示してあるが，いずれも片持ばり固定端の初 等ばり理論による值 $\left(\sigma_{0}\right)_{x=0}$ で無次元化してあ る.

まず，等分布荷重が満載する場合, 図一3よ り明らかなように $x=0.2 l$ 付近より Negative shear lag がおこりはじめ, ほぼ $x=0.6 l$ 付 近で初等ばり理論との差が最大となり，それ以 上 $x$ が大となると再び減少する傾向になる. しかしながら，固定端付近では単純ばりと同様 な shear lag 現象を呈する.

次に，集中荷重が載荷する 図一4の場合， Negative shear lag 現象は載荷点で最大とな ることがわかる．また着目点 $x \geq c$ の断面にお いても Negative shear lag の影響のために垂直応力が 発生することを示している。これは初等ばり理論による ものと著しく異なる点である. 以上の結果は，デッキプ レートに縦リブが取付けられていない簡単な断面に対し て計算された Kuhn の結果 ${ }^{4)}$ と傾向がよく一致してい る.

\section{（2） Negative shear lag の生ずる範囲亡最大值}

\section{a）等分布荷重が満載する場合}

Negative shear lag の生ずる範囲は, すでに示した 式 (27) で明らかなように曲げモーメント $M$ と shear lag による付加モーメント $m$ とが異符号のときにおこ る. それで, 付加モーメント $m$ のスパン方向の変化を 調べれば Negative shear lag のおこる範囲とその最大 值を知ることができる. 以下では, 付加モーメントを無

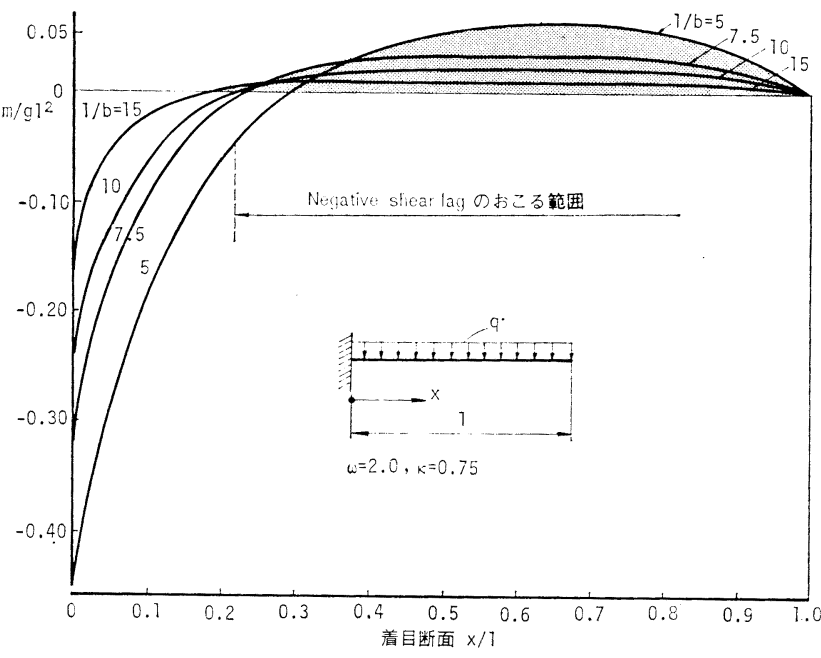

図一5 $l / b$ 值による $m / q l^{2}$ の変化

次元量として表わすために $q l^{2}$ で割り， $m / q l^{2}$ の值とし て求めることにする.

図一5 はパラメーター $\omega, \kappa$ を一定とし， $l / b$ にる $m / q l^{2}$ 值の変化をプロットしたものである. 着目点が $x / l<0.2$ では $m$ の符号は負であり, 曲げモーメントの 符号とも一致するから，通常の shear lag がおこること を意味する.しかし， $x / l>0.2$ の範囲では $m$ と $M$ の 符号が反転するので Negative shear lag がおこること になる・

そして，その最大值は $x / l \cong 0.6 \sim 0.7$ 付近におこり， $l / b$ 值が小さいほど $m / q l^{2}$ 值が大きく, したがって Negative shear lag が大きくなることを示している.

当然のことであるが, Negative shear lag のおこる 範囲とその最大值は，他のパラメーターによっても左右 される.それで，デッキプレートの特性を表わすパラ 
メーター $\omega$, および, 栴の断面形状を表わすパラメー ター による $m / q l^{2}$ 值の変化をそれぞれ 図一6〜7 に 示す.

これらの図によると, $\omega$ が大きいほど Negative shear lag が大きくなるが，几による影響はそれほど大きく現 われない。

以上の結果より, 等分布荷重を満載した片持ばりにお

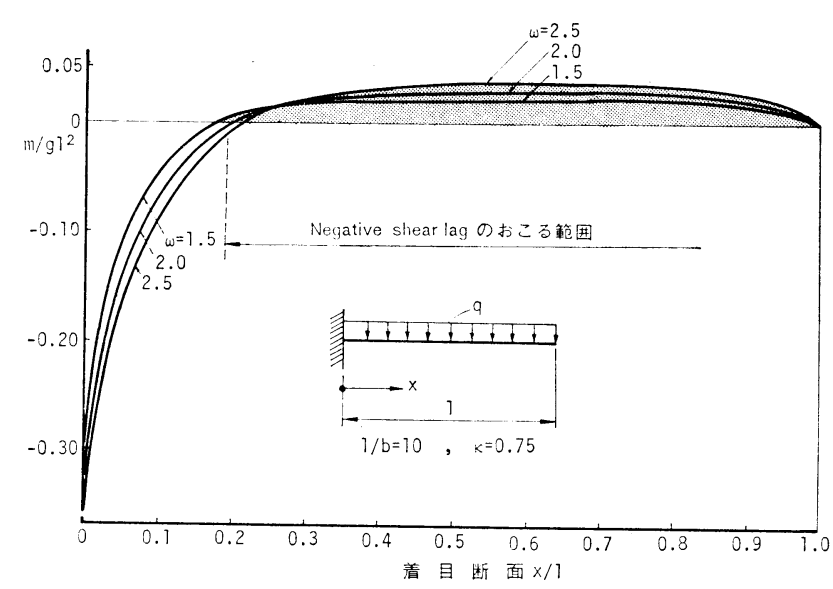

図一6 パラメーター $\omega$ による $m / q l^{2}$ の変化

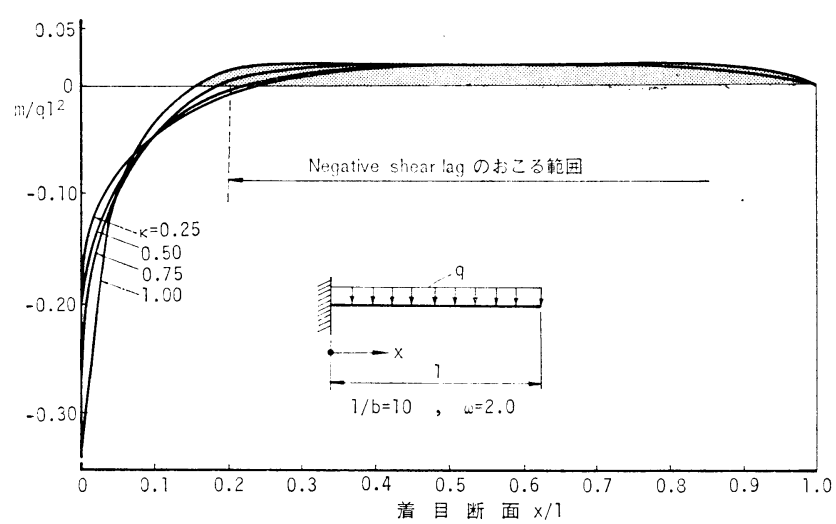

図一7 パラメーター $\boldsymbol{x}$ による $m / q l^{2}$ の変化
ける Negative shear lag の特性が明らかになったが， 実用的には 図一8に㧍いて点線で示す $m / q l^{2}$ 值の変化 を実線で示すような提案曲線で近似しても誤差は少ない ように思われる.すると, Negative shear lag のはじ まる位置 ば，付加モーメント $m$ のスパン方向の分布を容易に知 ることができる. そのため 表一9, 10 にはパラメータ 一 $l / b, \omega, \kappa$ に応じた $\psi$ および $\left(m / q l^{2}\right)_{\text {max }}$ 值を示した. 後述するように連続桁を片持式架 設工法で建設する際の Negative shear lag を 考虑した応力解析はこれらの表を利用して行う ことができ，有用な資料を提供するものと思わ れる.

\section{b）集中荷重が載荷する場合}

集中荷重が作用する場合, 図一4に示したよ らに載荷点直下において Negative shear lag が最大となる．そこで，着目点と載荷点とが一 致する $x=c$ の場合について, 付加モーメン 卜 $m$ を $P l$ で無次元化し, パラメーター $l / b$,

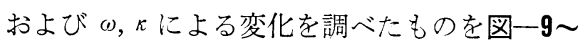
11 に示す.

これらの図より $l / b$ が小さいほど, $\omega$ あるい は が大きいほど $m / P l$ 值が大きくなること

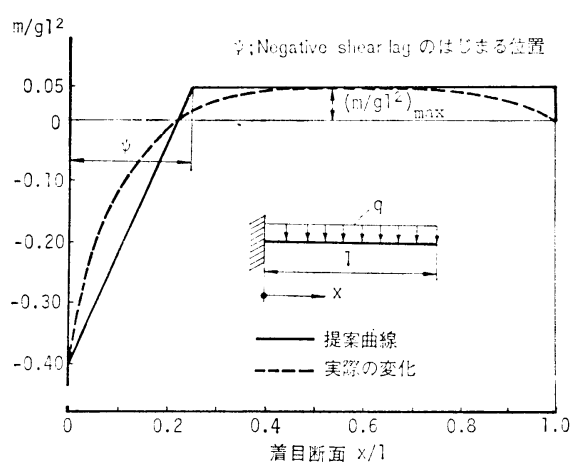

図一8 $m / q l^{2}$ 曲線に対する提案曲線
表一9 Negative shaer lag のはじまる位置

\begin{tabular}{c|c|c|c|c|c|c|c}
\hline \multicolumn{2}{c|}{$l / b$} & 3 & 5 & 7.5 & 10 & 15 & 20 \\
\hline \multirow{3}{*}{$\kappa=0.25$} & $\omega=1.5$ & 0.49 & 0.38 & 0.31 & 0.27 & 0.20 & 0.18 \\
& $\omega=2.0$ & 0.51 & 0.41 & 0.33 & 0.29 & 0.22 & 0.20 \\
& $\omega=2.5$ & 0.55 & 0.43 & 0.35 & 0.31 & 0.22 & 0.20 \\
\hline \multirow{5}{*}{$\kappa=0.50$} & $\omega=1.5$ & 0.45 & 0.35 & 0.29 & 0.23 & 0.20 & 0.18 \\
& $\omega=2.0$ & 0.48 & 0.38 & 0.31 & 0.26 & 0.21 & 0.18 \\
& $\omega=2.5$ & 0.52 & 0.41 & 0.33 & 0.28 & 0.22 & 0.18 \\
\hline \multirow{5}{*}{$\kappa=0.75$} & $\omega=1.5$ & 0.39 & 0.32 & 0.24 & 0.20 & 0.17 & 0.13 \\
& $\omega=2.0$ & 0.44 & 0.34 & 0.27 & 0.22 & 0.19 & 0.16 \\
& $\omega=2.5$ & 0.46 & 0.36 & 0.30 & 0.23 & 0.20 & 0.17 \\
\hline \multirow{3}{*}{$\kappa=1.00$} & $\omega=1.5$ & 0.33 & 0.24 & 0.19 & 0.17 & 0.11 & 0.10 \\
& $\omega=2.0$ & 0.36 & 0.28 & 0.21 & 0.19 & 0.13 & 0.10 \\
& $\omega=2.5$ & 0.38 & 0.29 & 0.22 & 0.20 & 0.16 & 0.10 \\
\hline
\end{tabular}

表一10 $\left(\boldsymbol{m} / \boldsymbol{q} \boldsymbol{l}^{2}\right)_{\max }$ の值 （等分布花重）

\begin{tabular}{c|c|c|c|c|c|c|c}
\hline \multicolumn{2}{c|}{$l / b$} & 3 & 5 & 7.5 & 10 & 15 & 20 \\
\hline \multirow{3}{*}{$\kappa=0.25$} & $\omega=1.5$ & 0.050 & 0.039 & 0.024 & 0.014 & 0.007 & 0.004 \\
& $\omega=2.0$ & 0.048 & 0.044 & 0.029 & 0.019 & 0.009 & 0.005 \\
& $\omega=2.5$ & 0.045 & 0.047 & 0.034 & 0.022 & 0.011 & 0.006 \\
\hline \multirow{3}{*}{$\kappa=0.50$} & $\omega=1.5$ & 0.067 & 0.045 & 0.025 & 0.015 & 0.007 & 0.004 \\
& $\omega=2.0$ & 0.068 & 0.053 & 0.032 & 0.019 & 0.009 & 0.005 \\
& $\omega=2.5$ & 0.066 & 0.058 & 0.037 & 0.024 & 0.011 & 0.006 \\
\hline \multirow{3}{*}{$\kappa=0.75$} & $\omega=1.5$ & 0.093 & 0.052 & 0.026 & 0.015 & 0.007 & 0.004 \\
& $\omega=2.0$ & 0.101 & 0.064 & 0.034 & 0.020 & 0.009 & 0.005 \\
& $\omega=2.5$ & 0.104 & 0.073 & 0.041 & 0.025 & 0.011 & 0.006 \\
\hline \multirow{3}{*}{$\kappa=1.00$} & $\omega=1.5$ & 0.137 & 0.059 & 0.027 & 0.015 & 0.007 & 0.004 \\
& $\omega=2.0$ & 0.164 & 0.076 & 0.035 & 0.020 & 0.009 & 0.005 \\
& $\omega=2.5$ & 0.185 & 0.092 & 0.044 & 0.025 & 0.011 & 0.006 \\
\hline
\end{tabular}




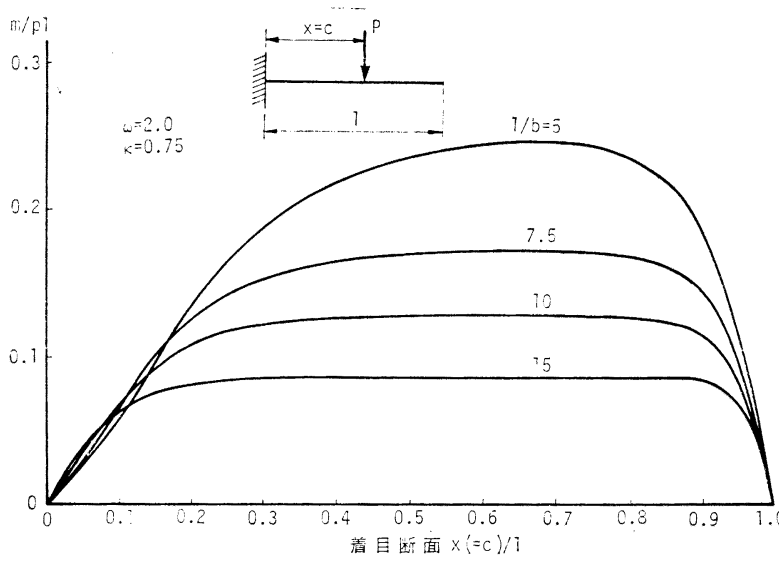

図一g $\quad l / b$ による $m / P l$ の変化

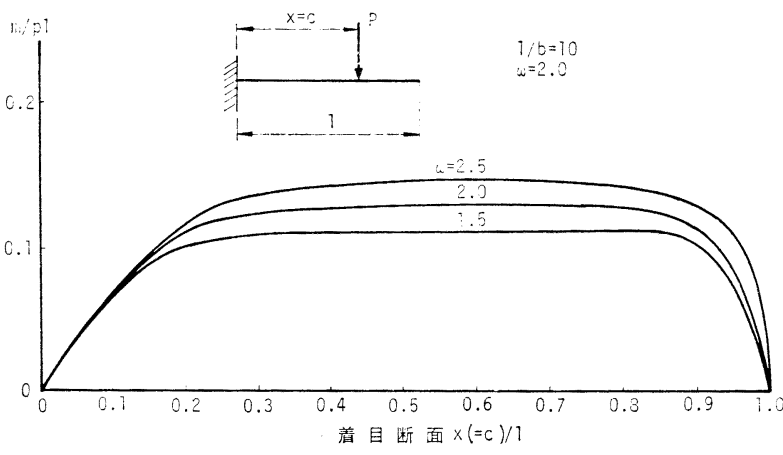

図一10 $\omega$ による $m_{i} / P l$ の変化

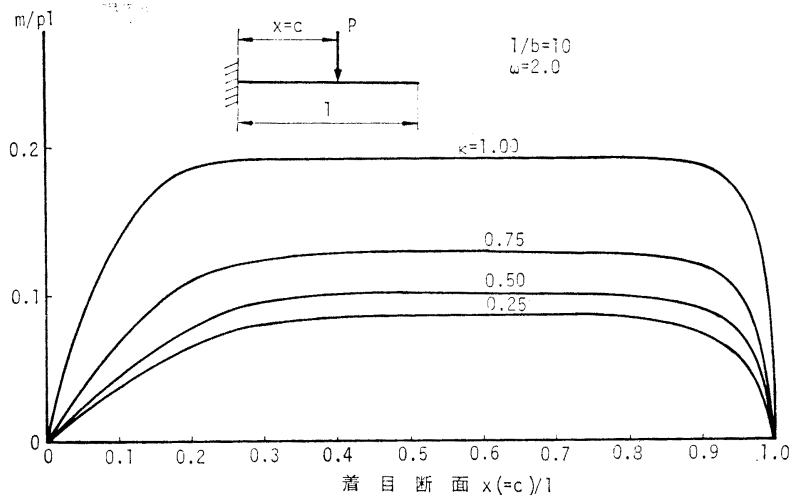

図一11 $\boldsymbol{\kappa}$ による $\boldsymbol{m} / \mathrm{Pl}$ の変化

がわかる．同様に，これらの結果をまとめると，図一12 の点線で示す曲線が得られる. そこで, 荷重点直下に対 する実用的な曲線としては, 実線で示す提案曲線で近似 することができる. 図一12 の折曲点 $/$ 值は, 種々な計 算結果より 図一8に示した 值とほぼ一致する傾向に あることがわかった．また， $(m / P l)_{\max }$ 值の各種パラ メーターによる変動を計算すると, 表一11 に示す結果 が得られる。

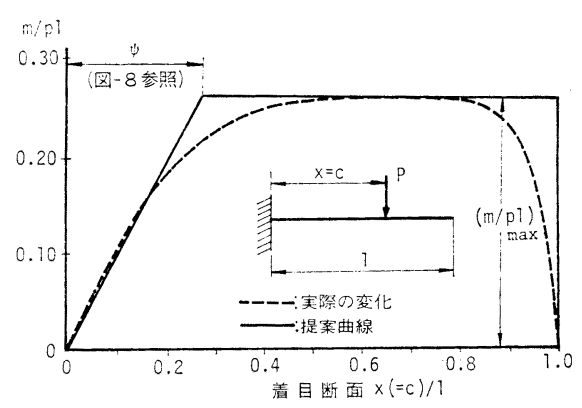

図一12 $m / P l$ 曲線に対する提案曲線

表一11 $(\boldsymbol{m} / \boldsymbol{P l})_{\max }$ の值（集中荷重）

\begin{tabular}{c|c|c|c|c|c|c|c}
\hline \multicolumn{2}{c|}{$l / b$} & 3 & 5 & 7.5 & 10 & 15 & 20 \\
\hline \multirow{4}{*}{$\kappa=0.25$} & $\omega=1.5$ & 0.169 & 0.139 & 0.101 & 0.077 & 0.051 & 0.039 \\
& $\omega=2.0$ & 0.168 & 0.151 & 0.141 & 0.088 & 0.059 & 0.044 \\
& $\omega=2.5$ & 0.165 & 0.159 & 0.125 & 0.098 & 0.066 & 0.050 \\
\hline \multirow{4}{*}{$\kappa=0.50$} & $\omega=1.5$ & 0.223 & 0.169 & 0.119 & 0.090 & 0.060 & 0.045 \\
& $\omega=2.0$ & 0.229 & 0.187 & 0.136 & 0.103 & 0.069 & 0.052 \\
& $\omega=2.5$ & 0.229 & 0.200 & 0.150 & 0.115 & 0.077 & 0.058 \\
\hline \multirow{4}{*}{$\kappa=0.75$} & $\omega=1.5$ & 0.318 & 0.219 & 0.149 & 0.112 & 0.075 & 0.060 \\
& $\omega=2.0$ & 0.339 & 0.247 & 0.171 & 0.129 & 0.086 & 0.065 \\
& $\omega=2.5$ & 0.349 & 0.270 & 0.191 & 0.144 & 0.096 & 0.072 \\
\hline \multirow{4}{*}{$\kappa=1.00$} & $\omega=1.5$ & 0.539 & 0.335 & 0.224 & 0.168 & 0.112 & 0.084 \\
& $\omega=2.0$ & 0.604 & 0.385 & 0.258 & 0.194 & 0.129 & 0.097 \\
& $\omega=2.5$ & 0.654 & 0.429 & 0.289 & 0.217 & 0.144 & 0.108 \\
\hline
\end{tabular}

\section{4. 模型実験}

上で述べた Negative shear lag の解析式の 妥当性を検討するために, 以下のような実験を 行った.

\section{（1）模型桁と実験装置}

模型桁は入手が容易な [ 形鋼 ( SSC-41 材) に平鋼（SS 41 材）のフランジを溶接し, 図一 13 に示すような II 形断面の片持ばりになるよ らに加工した。ただし，縦リブの影響は文献 8) で理論的・実験的に十分検討されているので, ここでは省略した。この片持ばりの端部には Sole plate を溶接し, 高力ボルト（F８T, M 22）によって既設の構造物実験フレームの柱に 固定した.

荷重は手動の油圧ジャッキ3台を用いて載荷し, 図一 14〜17 に示すような 種々な載荷状態が可能なようにし た.

一方, ひずみゲージ，ダイヤルゲージによって応力や たわみを測定したが，その取付位置は 図一13 に示すと おりとした。

なお，模型桁の材料試験は今回とくに行っていない 

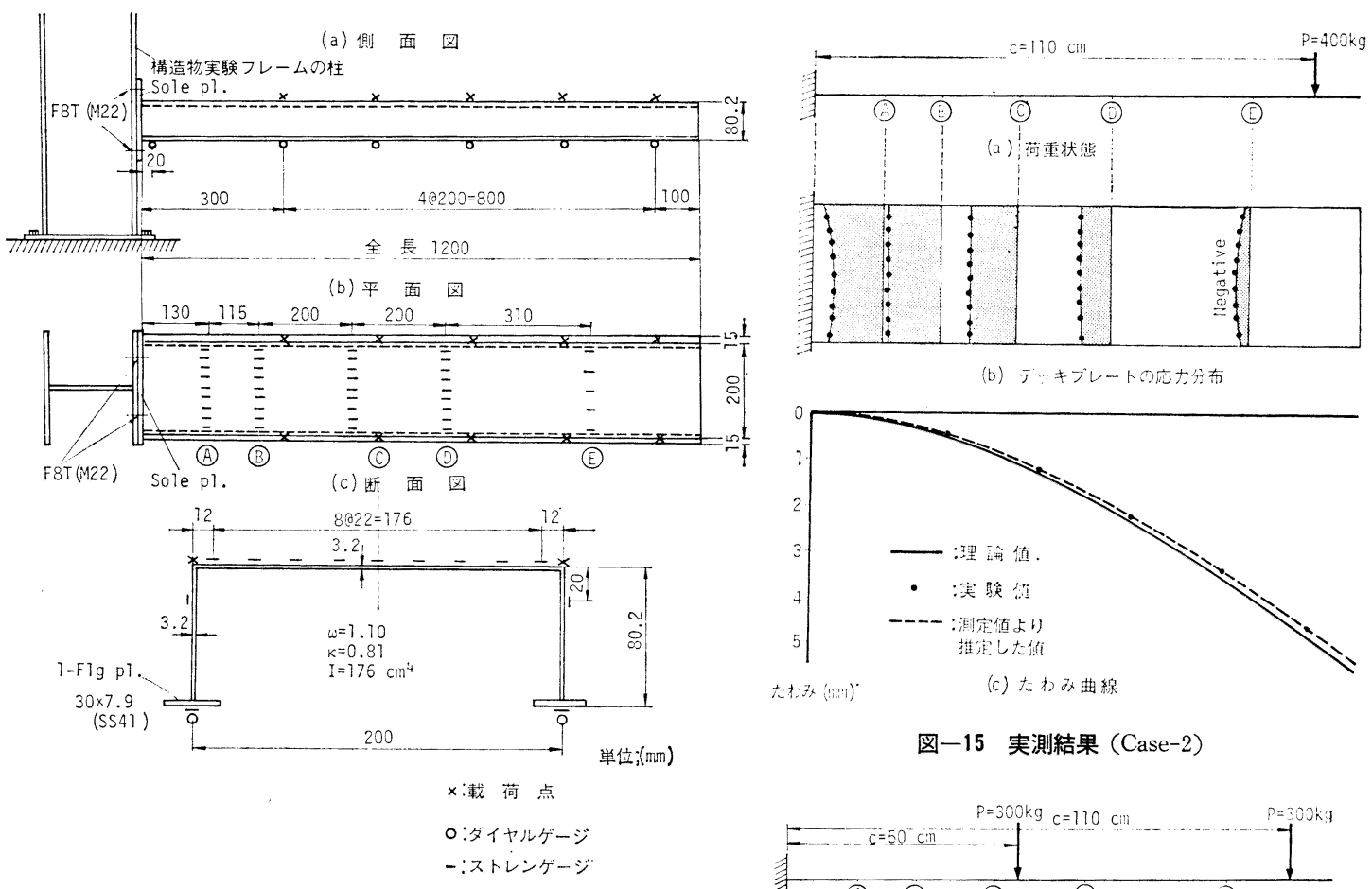

(b) デキキブレートの応力分布

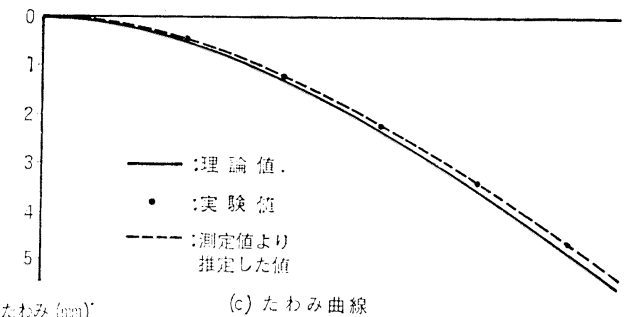

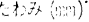

(c)たわみ曲線

図-15 実測結果 (Case-2)

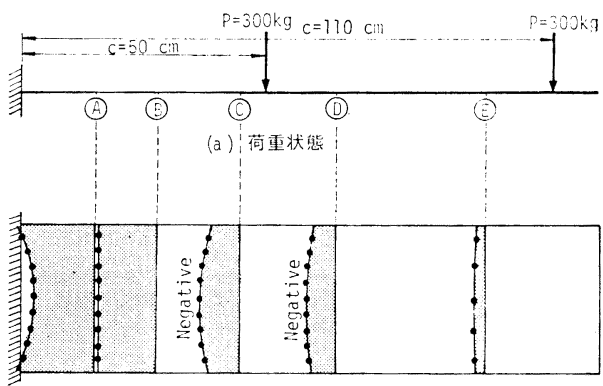

(b)テッキプレートの応力分布

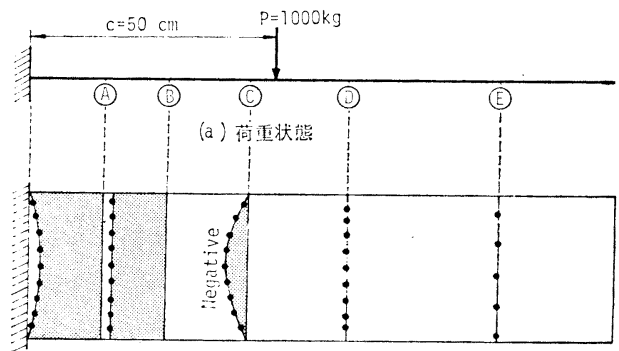

(b)デッキブレート空力分布

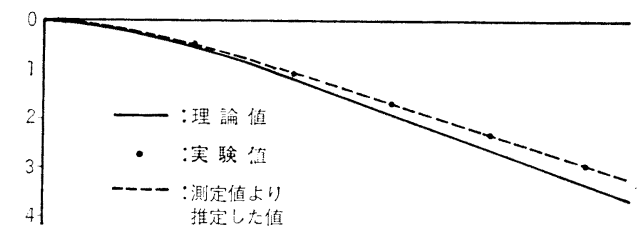

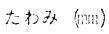

（c）たれみ曲線

図-14 実測結果 (Case-1)

が, ヤング率 $E=2.1 \times 10^{6} \mathrm{~kg} / \mathrm{cm}^{2}$, ポアソン比 $\nu=0.3$ として実験データを整理することにした.

\section{(2) 実験結果とその考察}

4 ケースの荷重状態に対して実験した結果を図一14〜 17 に示す. いずれの場合も, 固定端近傍の応力分布は, Sole plate を通じてフレームの柱にボルト結合したた

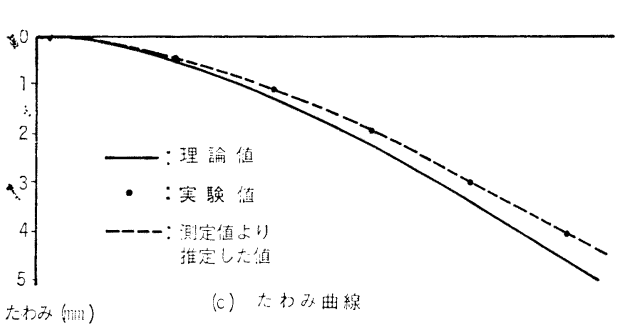

図-16 実測結果 (Case-3)

め応力の乱れが出たのでここでは省略したが，固定端か ら桁高以上離れた断面 (A)では St. Venant の原理によ り応力の乱れが消滅し, 通常の shear lag 現象が生じて いることが観察される.しかし，断面 B〜®において は理論で示したような反転現象が生じ, Negative shear lag 現象が観測される.特に, この現象は载荷点の多い Case 3〜Case 4 で顕著である.

また，これらの図中にはたわみの測定值（両側ウェブ の平均值）と理論值とを比較したものを示した．ただ しここでたわみの測定值には固定端となっている柱の 


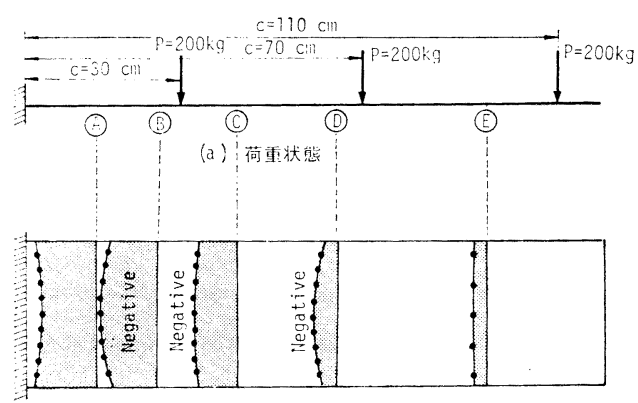

(b) デップレートの応力分布

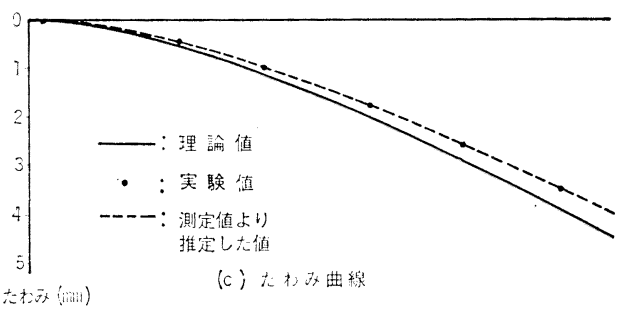

図-17 実測結果 (Case-4)

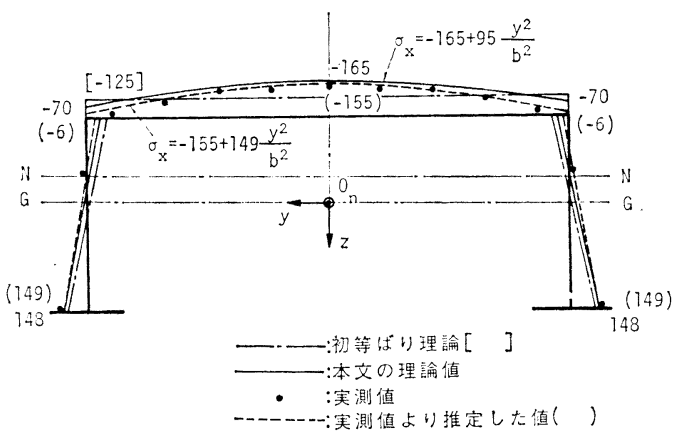

図-18 垂直応力分布 (Case-1)

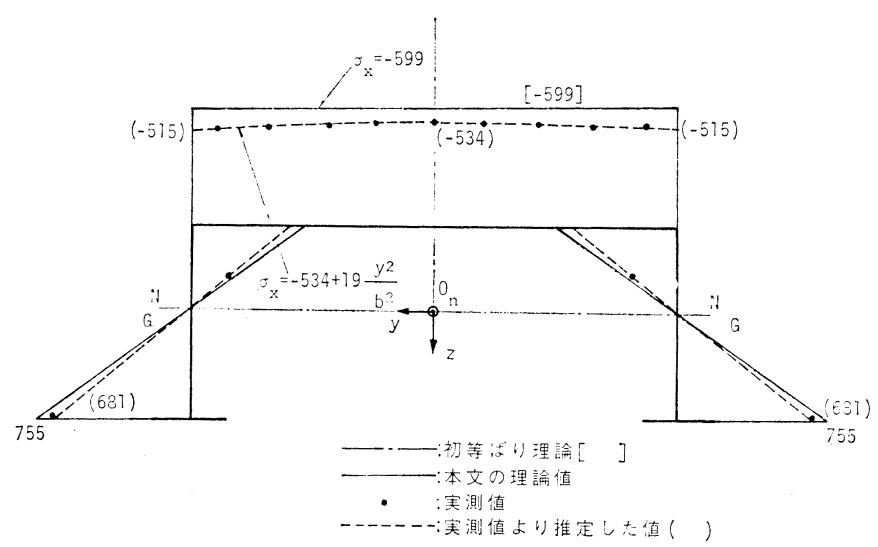

図-19 垂直応力分布 (Case-2)

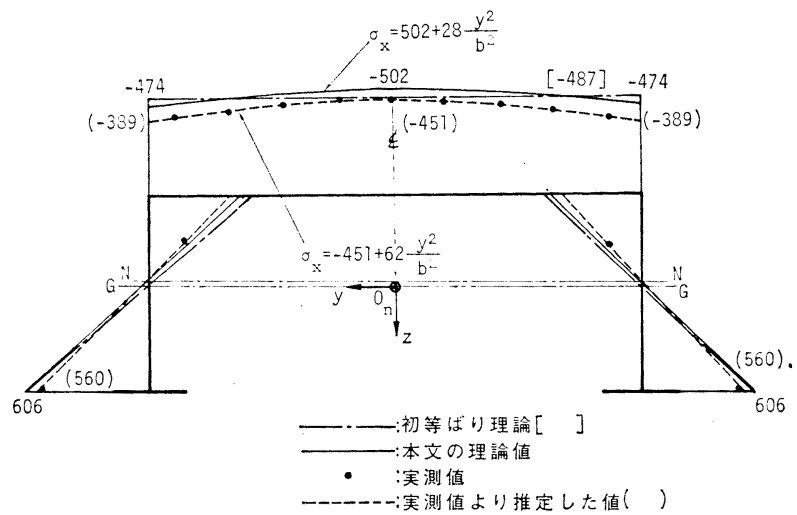

図一20 垂直応力分布 (Case-3)

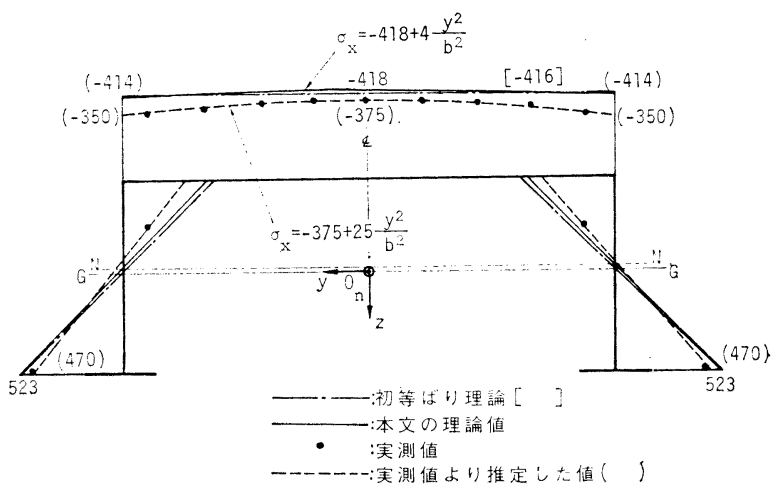

図-21 垂直応力分布 (Case-4)

弾性変形の影響が現われたので，これを補正するために たわみ曲線が 3 次の放物線と仮定して最小自乗法により 定数を求め, 固定端におけるたわみとたわみ角が共に0 となるような修正を行ったものである. 一方, 理論值の ほうにも桁のせん断変形によるたわみを考慮している. 以上のような補正をした実測值と理論值とを比較すれ

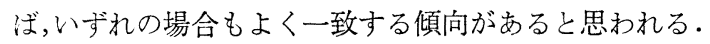

次に, 桁各部の応力分布の詳細を知るた めに, 断面 (C)内の垂直応力分布をプロット したものを図一18〜21 に示す. デッキプ レートの実測応力は若干ばらついているの で，理論上の仮定 ${ }^{8)}$ にしたがって 2 次放物 線状に変化するとして最小自乗法で推定值 を求めたものも示したが，このような処理 を行うと理論值とよく一致した結果が得ら れているように思われる.

以上, 応力分布やたわみの実測值と理論 值との比較から, 本文の Negative shear lag の解析方法の妥当性が十分に確か内ら れたように思われる。 


\section{5. 連続椼, 斜張橋の応力解析への応用}

\section{(1) 連 続 桁}

\section{a）片持式架設中の連続桁}

図一22に示すように，連続桁を片持式架設する際の Negative shear lag による垂直応力を計算する.

置換ばりは 図一23 に示すように片持ばりであり，こ れに死荷重 $q=4.0 \mathrm{t} / \mathrm{m}$ が載荷するものとする. 図一22 (b) に示すパラメーター $l / b, \omega, \kappa$ 值から Negative shear lag の生ずる位置市を表一9より求めると

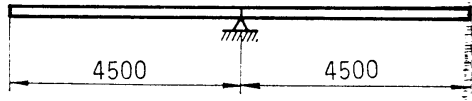

(a) 側面図

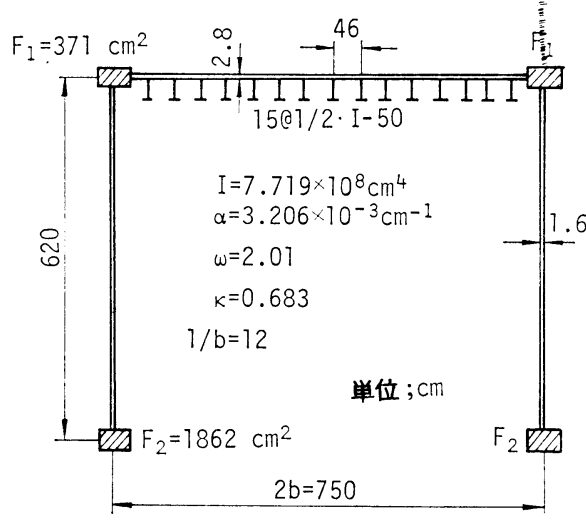

(b) 断面図

図一22 片持式架設中
0.22 , すなわち着目点 $x=\psi l=9.9 \mathrm{~m}$ となる. また, 表一10より, $\left(m(x) / q l^{2}\right)_{\max }=0.015$ であるから着目点 における付加モーメントは $m=122 \mathrm{tm}$ となる．初等ば り理論によるこの点のモーメントは $M=-2464 \mathrm{tm}$ で あるので, 式 (27), (28) より $\sigma_{m}=102.2 \mathrm{~kg} / \mathrm{cm}^{2}, \sigma_{s}=$ $5.0 \mathrm{~kg} / \mathrm{cm}^{2}$ が得られ, 垂直応力分布を式 (29)にしたが ってプロットすれば 図一24のようになる.

なお，参考までに片持ばり固定端の有効幅の算定公式 は, 定義式 $b_{m}=\int_{0}^{b} \sigma_{x} d y_{1} /\left[\sigma_{x}\right]_{y_{1}=b}$ より次式のように書 くことができる.

$$
\frac{b_{m}}{b}=1-\frac{2 m(x)}{3 M(x)+2 \kappa m(x)}
$$

それで，固定端においては式 (32.1)，(35.1) より，そ れぞれ $M=-4050 \mathrm{tm}, m=-1515 \mathrm{tm}$ であるから, 式 (38) より有効幅を求めると $b_{m} / b=0.787$ になる.とこ ろで, Merrison 委員会の I.D.R ${ }^{9)}$ によると片持ばりの 有效幅は，そのスパンを 2 倍とした単純ばりに置換して 求めることを提案している。この提案にしたがって片持 ばり固定端の有效幅を文献 8) より求めてみると, $b_{m} / b$ $=0.801$ となり，その誤差は $1.8 \%$ にすぎない. したが って，片持ばりの固定端においてはスパンを 2 倍し，単 純ばりの有效幅の公式を利用してもあまり大きな䛊差が 生じないものと思われる.

図一25には固定端における垂直応力分布を示す.

b）不等スパン連続桁

図一26に示すように著しい不等スパンを有する 4 径 間連続桁に等分布満載荷重が作用する場合を考える.こ の場合は第 3 径間の支点が近接しているために，第 3 支 間中央においては負の曲げモーメントが卓越し，Negtive shear lag が生ずる.

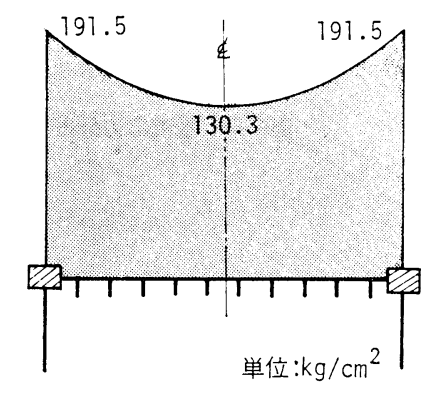

図一25 垂直応力 $\sigma_{x}$ の分布 $(x=0)$

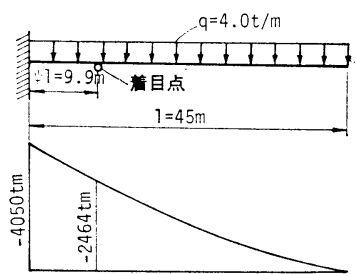

図一23置換ばり

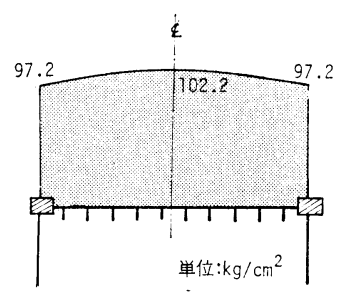

図一24 垂直応力 $\sigma_{x}$ の分布

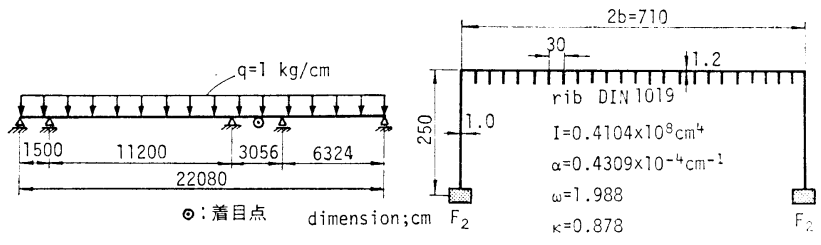

図一26 4 径間連続桁 


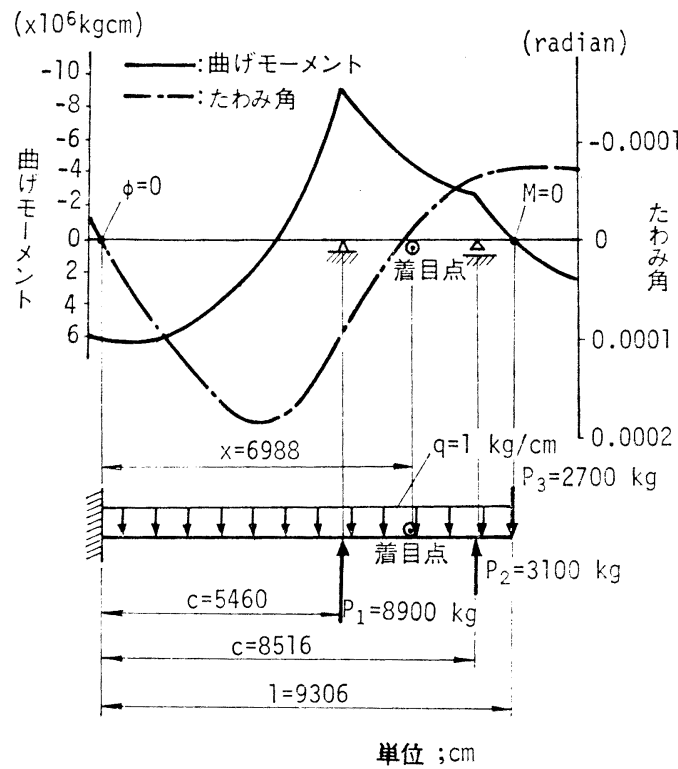

図一27置換ばり

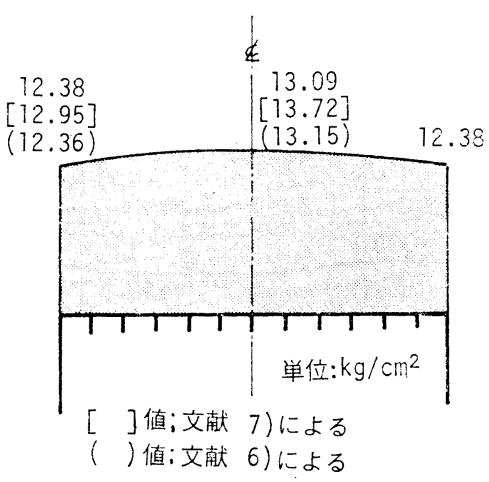

図一28 垂直応力 $\sigma_{x}$ の分布

これ老明らかにするために，まず連続楿に等分倠荷重 $q$ が載荷する際に対し，図一27に示すようにたわみ角 図と曲涊モーメント図をプロットする。すると，この連 続析流たわみ伤 $\varphi=0$ となる点を固定端とし, 曲げモー メント $M=0$ となる点を自由端とする片持ばりに置換 することができる. もちろん, 中間支点反力 $P_{1}, P_{2}$ ，お よび $M=0$ 点におけるせん断力 $P_{3}$ を集中荷重として 作用させておかなければならない，次に，各荷重による 着目断面の付加モーメント $m$ を式(35) 上り求めると次 のようになる.すなおち， $m_{p 1}=-1.47 \times 10^{4} \mathrm{~kg} \cdot \mathrm{cm}$ ， $m_{p_{2}}=-0.23 \times 10^{4} \mathrm{~kg} \cdot \mathrm{cm}, m_{p_{3}}=0, m_{q}=25.05 \times 10^{4} \mathrm{~kg}$. $\mathrm{cm}$ となり, 全付加モーメントは $m=23.35 \times 10^{4} \mathrm{~kg} \cdot \mathrm{cm}$ となる。一方, 曲げモーメントは $M=-420.74 \times 10^{4}$ $\mathrm{kg} \cdot \mathrm{cm}$ であるから式 (32) より， $\sigma_{m}=13.09 \mathrm{~kg} / \mathrm{cm}^{2}, \sigma_{s}$ $=0.71 \mathrm{~kg} / \mathrm{cm}^{2}$ となる. 図一28 は第 3 径間中央の着目断 面におけるデッキプレートの垂直応力の分布を示したも

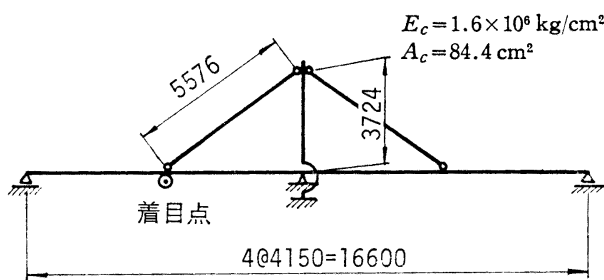

単位: $\mathrm{cm}$

（a）側面図

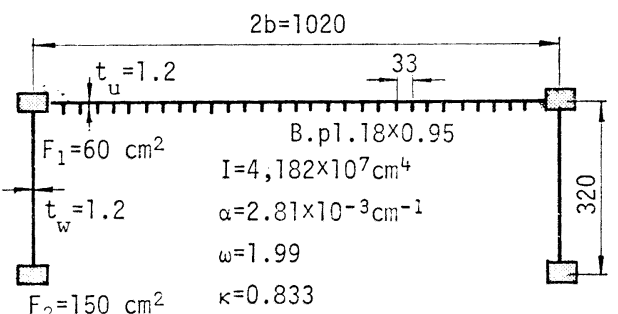

(b) 断面図

図一29 斜 張 橋

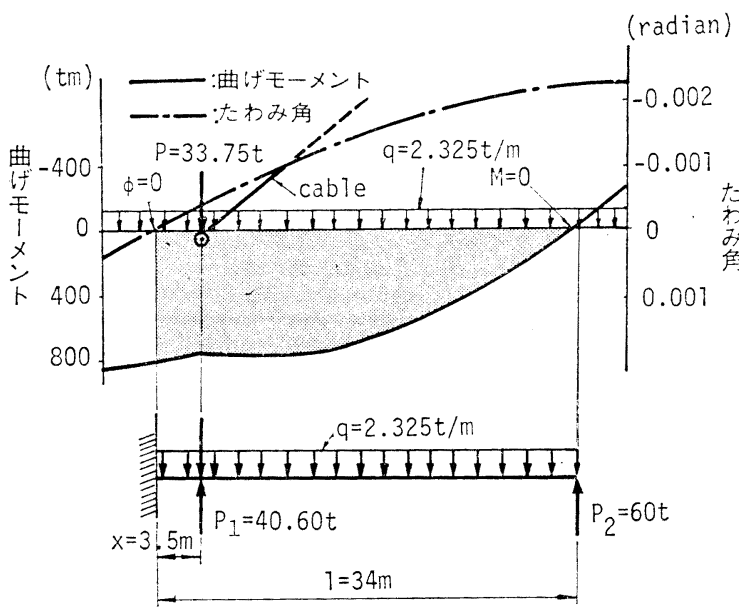

図一30 瞄換ばり

のであり, Negative shear lag が発生していることが わかる．また，文献 6)，7）による計算值も図中に示し てあるが，良好な一致がみられ，上述の上うに連続桁を 片持ばりに置換する方法が妥当であるように思われる。

\section{(2) 斜 張 橋}

a) 例 1

図一29 は斜張橋の側面図と断面図を示したものであ $る^{10)}$. 斜張橋のケーブル取付点に最も不利となるような $L$ 荷重を載荷したときのたわみ角と曲げモーメントを 図一30 に示す．連続桁と同样にたわみ角 $\varphi=0$ 点を固 定端とし，曲げモーメント $M=0$ 点を自由端とする片 持ばりに置換する．もちろん，ケーブル取付点でのばね 
反力, および $M=0$ 点でのせん断力を荷重として作用 させる.そして，同様な計算過程によって求められたケ 一ブル取付点右側の断面における垂直応力の分布を図一 31 に示す. ただし, 軸力による垂直応力は別途計算し て, 曲げによる垂直応力に加算した。この図から明らか なように, この斜張橋のケーブル取付点には Negative shear lag が生じる. また, 本文の方法で求めた垂直応 力は文献 7) の方法によるものとよく一致することがわ かる.

b) 例 2

図一32 に示すような豊里大 橋 ${ }^{11)}$ の断面諸量を参考にし，ケ ーブルの多数ある斜張橋のケー ブル取付点におけるデッキプレ 一トの垂直応力の計算例を示す. まず，着目点 1 に最も不利な 応力状態になるよらに， $L$ 荷 重を載荷した際の断面力・変形 量を文献 11) の方法で求め, 片

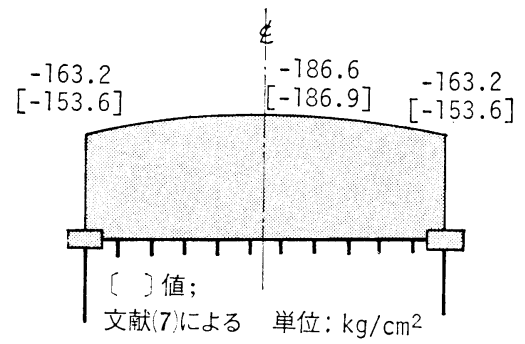

図一31 垂直応力 $\sigma_{x}$ の分布

ケーブルのヤング率 $2.0 \times 10^{7} \mathrm{t} / \mathrm{m}^{2}$

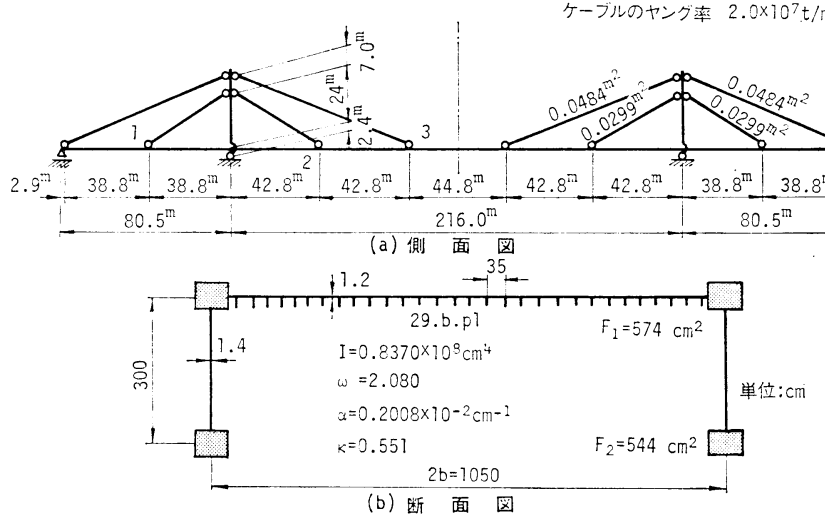

図一32 斜 張 橋

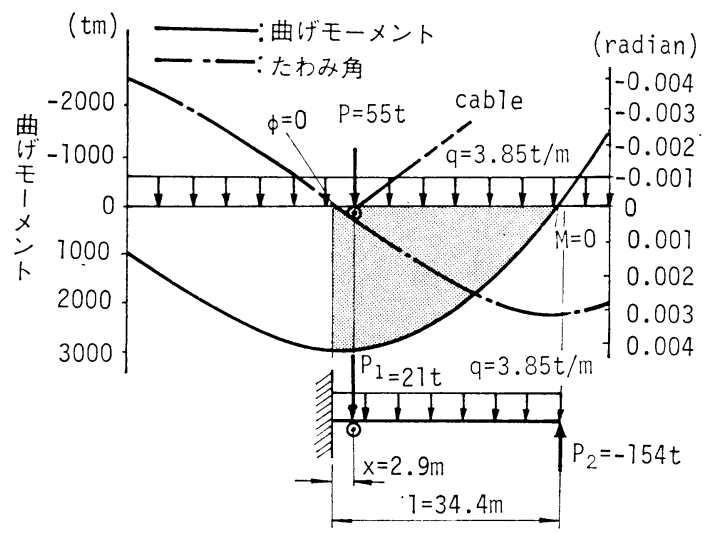

図一33置換ばり（着目点 1)
持ばりに置換したものを 図一33 に示す。またデッキ プレートの垂直応力の分布を 図一34 にプロットした. 同様に着目点 2 ，および，3に関する置換ばりとデッキ プレートの垂直応力の分布図を，それぞれ 図一35, 36 に示寸.

以上の計算結果より着目点 1,2 では通常の Shear lag が生じているが，着目点 3 においては Negative shear lag が生じていることがわかる。このようにケーブルが 多数取付けられた斜張橋では, 必ずしも Negative shear

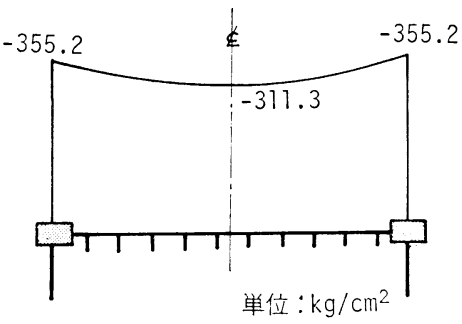

図一34 垂直応力 $\sigma_{x}$ の分布

(着目点 1)

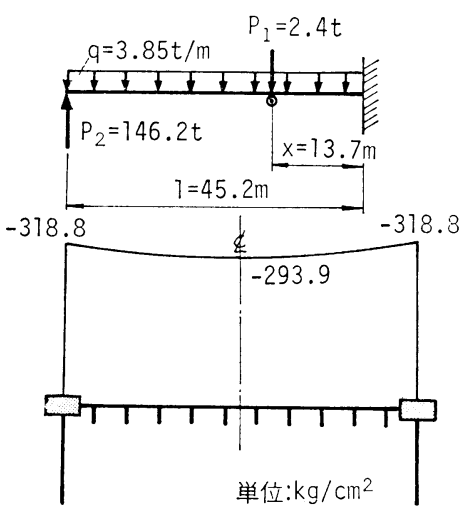

図一35 置換ばりと垂直応力 $\sigma_{x}$ の分布 （着目点 2 ）

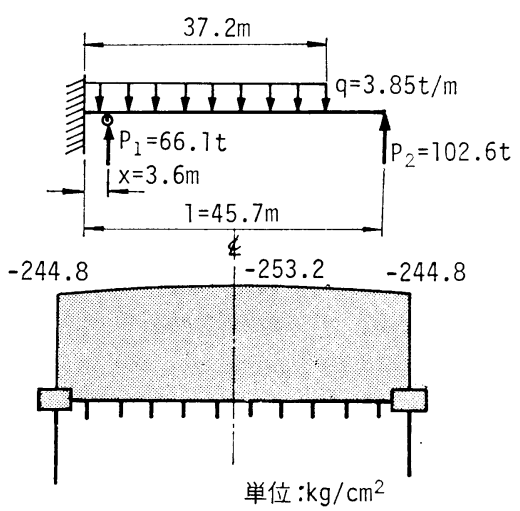

図一36 置換ばりと垂直応力 $\sigma_{x}$ の分布 （着目点 3 ) 
lag が生じるとはかぎらない. しかし, ザイル取付点で 生じた通常の Shear lag は連続桁の中間支点のところ に生じるものよりかなり緩和されたものであり，斜張橋 を設計する際このような点を十分考慮すべきであると考 える.

\section{6. むすび}

本文は，片持ばりに生ずる Negative shear lag の特 性を明らかにし, この結果を連続桁や斜張橋の応力解析 に応用する方法を述べたものである。おもな結論を列記 すると，以下のようである。

（1）片持ばりに各種の荷重が載荷する際の Shear lag 現象を解析する基本公式を示した.

（2）片持ばりの Negative shear lag がおこる範囲 や最大值の変化状態をパラメトリック解析し, 実用計算 に便利な図表にまとめた。

（3）模型実験を行い，本文の理論上の仮定や解析結 果の妥当性を確かめた。

(4) 橋梁構造物として使用される機会の多い連続妳 橋や斜張橋において Negative shear lag が生ずること を数值計算例によって示した.

以上によって, この種の構造物を設計する際, 今後は 通常の Shear lag のほかに Negative shear lag を考
慮すべきであることを示すことができ，これに関する一 つの資料が提供できたものと考える.

\section{参考 文 献}

1) Timoshenko, S.P. and Goodier, J.N. : Theory of Elasticity 3rd, Ed, McGraw-Hill, pp. 262 268, (1970)

2) Girkmann, G. : Flächentragwerke, Dritte Auflage, Springer-Verlag, s. 116 124, (1954)

3) Reissner, E. : Quart. Appl. Math., Vol. 4, p. 268, (1946)

4) Kuhn, P. : Stresses in Aircraft and Shell Structures, McGraw-Hill, p. 139, (1956)

5）林 孝哉：日本航空宇宙学会誌, Vol. 22, No. 243, pp. 194 199, (1974.4)

6）小松定夫：連続街の Shear lag 汇ついて, 土木学会論文 集 58 号, pp. 1 9, (1958.9)

7）中井 博・事口寿男：伝達マトリックス法による銅床版 桁橋の有効幅の解析, 土木学会論文報告集, pp. 29 44, (1976.7)

8）近藤和夫・小松定夫・中井 博：鋼床版桁橋の有効幅化 関する研究，土木学会論文集 86 号, pp. 1 17, (1962.10)

9) Inquiry into the Basis of Design and Method of Erection of Steel Box Girder Bridge, Interium Design and Workmanship Rules, Part I and Part II, London, Her Majesty's Stationery Office, (1973)

10）田村周平・苗吹昭光・出野 宏：尾道大橋の設計につい て, 橋梁, Vol. 4, pp. 58 67, (1968.6)

11) Nakai, H. and Nakanishi, M. : Statical Analysis of Cable-Stayed Girder Bridges, Memoirs of the Faculty of Engineering, Osaka City University, Vol. 12, pp. 197 218, (1971.12)

(1976.2.16 • 受付) 